\title{
Patterns and Regularities of Psychophysical Development of Early Age Children with Neurological Pathology
}

\section{Закономірності психофізичного розвитку дітей раннього віку з неврологічною патологією}

\section{Irina Valitova}

Ph.D. in Psychology, Assistant Professor, Professor of the Department of Social Work, Brest A. S. Pushkin State University, Brest (Republic of Belarus)

ORCID ID: https://orcid.org/0000-0003-0751-8534

E-mail: irvalitova@yandex.ru

\section{Ірина Валітова}

Кандидат психологічних наук, доцент, професор кафедри соціальної роботи, Брестський державний університет ім. О. С. Пушкіна, м. Брест (Республіка Білорусь)

\section{ABSTRACT}

The aim of the article is to describe the characteristics and to identify individual types of psychophysical development of children with neurological pathology in the early age.

Research methods. Munich Functional Diagnostics Development was used to assess children's developmental age, which highlights the areas of child development: motor development, fine motor skills development, perception development, the development of speech and language comprehension, social development, autonomy development. The concept «developmental age» is understood as the level of child development in each sphere. Study sample: children aged

Address for correspondence, e-mail: kpnu_lab_ps@ukr.net Copyright: (C) Valitova Irina

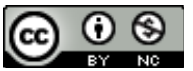

The article is licensed under CC BY-NC 4.0 International

(https://creativecommons.org/licenses/by-nc/4.0/)

(c) Valitova Irina

DOI (article): https://doi.org/10.32626/2227-6246.2021-52.09-38 
from one to three years with neurological diagnoses of cerebral palsy $(n=99)$ and CNS PROP $(n=201)$.

Results of the study. The indicators of developmental age in all spheres increase with the increase of child chronological age, which indicates the $d y$ namics of psychophysical development in the period from one to three years. The value of the indicator of the discrepancy between the chronological age and the age of development increases by children of the third year of life compared to the children of the second year of life, which means that development speed of children slows down. Based on a set of criteria six types of child development profiles which are presented in the general sample with different frequency, were identified: the most common profiles are those with a significant decrease in the developmental indicators, less often - profiles with a slight decrease in the developmental indicators and the profile with an excess of chronological age indicators is found in rare cases. The types of development profiles are not strictly related to nosological categories.

Conclusions. The developmental profile reflects the structure of the defect, and allows to define backward and intact function as well as to set objectives for remedial work and to determine the zone of proximal development of the child. The established patterns of development of a child with a neurological pathology will be of interest to neurologists and also have practical significance for dealing with mothers, who have no idea about the slowing down of the child's development with age.

Key words: early age, psychophysical development, developmental disorders by children, neurological pathology, cerebral palsy, organic lesions of the central nervous system, patterns of developmental disorders, developmental profile.

\section{Introduction}

The problem of ensuring the successful psychophysical and psychoemotional development of a child in developmental psychology is currently being brought to the fore. Early age holds a special place in ontogenesis - it is characterized by a high tempo of psychophysical development, increased sensitivity to the influence of various hazards on the body and psyche as well as the high importance of the child's relationship with a close adult for its successful development. One of the priorities of (C) Valitova Irina

DOI (article): https://doi.org/10.32626/2227-6246.2021-52.09-38 
research and practice of pediatric neurology is neurological pathology by young children (Barashnev, 2001; Palchik, 2002). Early age is to be placed into the context of developmental disorders in the field of view of clinical science and practice due to its sensitivity to therapeutic and correctional effects. The effectiveness of the intervention under the influence of other factors is inevitably higher at its early stage and this requires the establishment of interdisciplinary clinical and psychological links. Cerebral pathology of children of an early age leads to disorders in their development in different areas due to lesions of the central nervous system as a biological prerequisite for psychophysical development. Studies of the patterns and dynamics of the psychophysical development of children with neurological pathology in the early age are necessary for the scientific justification of correctional and developmental aid programs.

Neurological pathology at an early age as a consequence of pre-and perinatal brain damage is characterized by a high level of prevalence. In the structure of children's disability, diseases of the system occupy the second place, and in 35-40\% of cases, the cause is pre-and perinatal damage of the central nervous system (Smychek, 2009; Palchik, 2002; Khachatryan, 2003). Lesions of the central nervous system of different etiologies are a biological prerequisite for developmental disorders in early childhood and act as a primary defect (Lebedinsky, 1985).

In this paper, two nosological categories of neurological pathology of early age are considered: the consequences of early organic damage of the central nervous system (CEOD CNS), in ICD-10: G96.8 - G96.9; and cerebral palsy (CP), in ICD-10: G80.1 - G80.4. If a child has a neurological pathology of this nosology, specific patterns of psychophysical development are observed. In the Russian-speaking approach, developmental disorders are considered in the logic of the regularities of normotypic development: the analysis of activities and commu-

(c) Valitova Irina

DOI (article): https://doi.org/10.32626/2227-6246.2021-52.09-38 
DOI: https://doi.org/10.32626/2227-6246.2021-52

2021. випуск 52

nication with adults as well as cognitive activity at a certain age stage, is carried out. In the foreign approach, the patterns of child development are considered in the logic of diagnostic tools and the level of its development in different spheres is assessed in accordance with the standards of diagnostic scales (Handbook, 2004) as well as psychometric criteria.

Evaluation of the features of the psychophysical development of children under the age of three years with Down syndrome, autism spectrum disorders and neurological pathology was carried out in the work of A. V. Kukuruza (2013) that described the characteristics of the motor, sensory, speech and cognitive development of children. The dependence of the characteristics of psychomotor and socio-emotional development of children on the type of nosology is established; a wide range of development indicators by children with Down syndrome is shown and difficulties in mastering object and play activities by children with motor disorders are emphasized.

From an early age a child with cerebral palsy is developed in specific conditions which determine his relationship with the surrounding world and the deficiency of the motor sphere causes the phenomena of motor, sensory, cognitive, social deprivation and violations of the emotional-volitional sphere (Lebedinsky, 1985). The insufficiency of higher mental functions by the type of mental underdevelopment and mental retardation was observed by children with cerebral palsy at the age of 1-3 years in 53\% of cases (Ermolenko et al., 2000).

A comprehensive study of O. G. Prikhodko (2008) concerning types and dynamics of child development with cerebral palsy at the second year of life has shown that all children were having motor disorders of varying severity (general motor skills, manual skills, articulatory motor skills) as well as delayed language development and variable specific disorders of different functions. The rate of motor, social, cognitive and speech development of children varies widely, characterized by (C) Valitova Irina

DOI (article): https://doi.org/10.32626/2227-6246.2021-52.09-38 
irregular dynamics in different spheres. Objective activity is formed with considerable delay since actions with objects are formed as the general motor skills improve. This leads to a delay in the formation of a holistic view about an object and to insufficient knowledge and ideas about the surrounding world (Kuznetsova, 2002; Mamaichuk, 2003).

The development of speech by children with cerebral palsy is carried out with a significant delay, which is caused by the defeat of the areas of the cerebral cortex responsible for the movement of the speech organs and the limitations of the child's practical experience, its social contacts (Mastyukova \& Ippolitova, 1985). Although the degree of speech development delay varies, $85 \%$ of two-year-old children with cerebral palsy have speech development delay relative to age standards (Arkhipova, 1989).

The development of speech comprehension by children with cerebral palsy is possible by several trajectories: children with anarthria and severe dysarthria have a significant delay in the development of speech comprehension (Hustad et al., 2018); children with impaired speech motor skills are characterized by a constant delay in the development of speech comprehension. Predictors of low communication development of children with cerebral palsy are gestational age that is less than 32 weeks, the appearance of first words after 24 months and the child's use of other communication tools rather than speech (Hidecker, 2018).

At an early age, children with cerebral palsy are characterized by a decrease in the speed of formation of the main forms of communication, the lack of full use of verbal and non-verbal means of communication and an insufficient degree of involvement of object-manipulative activities in communication (Krutyakova, 2011).

The result of early organic damage of the central nervous system is a decrease of the indicators of psychophysical deve-

(c) Valitova Irina

DOI (article): https://doi.org/10.32626/2227-6246.2021-52.09-38 
DOI: https://doi.org/10.32626/2227-6246.2021-52

2021. випуск 52

lopment of children in comparison with normally developing peers (Tishkova, 2004). Young children with an organic lesion of the central nervous system are characterized by variable characteristics of psychophysical development: they have deviations in speech, motor, mental, emotional-personal and social development. Most children aged 2-3 years with a residual organic lesion of the central nervous system have a lag of varying degrees in the development of motor, perceptual, intellectual, speech, and communication functions (Sindiak, 2007), more than $75 \%$ of children have severe and moderate motor and speech disorders.

The term "global developmental disorder» is used to assess developmental delay in children under 5 years of age when there is a lag of more than two standard deviations in two or more spheres of development (Voigt, 2017). However, a reliable, truthful and predictive diagnosis of mental development is possible only from the age of 4 or 5 , so it is recommended to avoid the concept of «mental impairment» or «intellectual reduction" in relation to children under 4 years of age (Peters, 2017).

Developmental disorders by children with mental retardation are observed at an early age and are manifested by a lag in the development of all spheres. All the basic movements such as grasping and actions with objects are formed late. Most children in their third year have incomplete stages of manipulative and first objective actions, lack of interest in cooperation with an adult (Bratkova, (2006) as well as delayed formation of self-service skills.

Early-age children with an organic lesion of the central nervous system lack prerequisites necessary for the formation of speech: actions with objects, emotional communication with an adult, the readiness of the articulatory apparatus and phonemic hearing. Most children with cognitive impairments develop first words of active speech after two years. Children of (C) Valitova Irina

DOI (article): https://doi.org/10.32626/2227-6246.2021-52.09-38 
24 months with cognitive impairment were at risk concerning their speech disorders (Zampini, 2018). Significant strong correlations were found between motor, cognitive and speech domains in the development of children with cognitive impairments (Houwe, 2016). The cognitive development of young children with speech delay is heterogeneous (Henry, 2018), and the delay in the verbal component of cognitive development is associated with a later diagnosis of autism spectrum disorder.

Comparing the characteristics of the psychophysical development of children with cerebral palsy and children with organic damage of the central nervous system, it is necessary to note a significant similarity: all children at an early age are diagnosed with developmental delays in all spheres compared to normal children. Developmental delays can be of varying degrees of severity and the child's development levels (respectively, the levels of developmental delays) in the motor, cognitive, speech and social spheres are closely related to each other. The differences between these categories of children lay in the ratio of primary and secondary defects. Thus the children with cerebral palsy have the primary defect as motor insufficiency (movement disorders) and the secondary defect is a violation in the development of all functions that include the motor component, which in turn includes violations in the development of all typical activities, attention and purposefulness, visual perception, practical thinking, the use of non-verbal means of communication as well as active speech. The children with early organic damage of the central nervous system have the primary disorder as a violation of intelligence or its basic components and the secondary - a violation of all other mental functions that are formed in close connection with intellectual development. In order to characterize the psychophysical development of children with neurological pathology properly, the degree of severity of cerebral disorders and the degree of severity of disorders of psychophysical development due to them must be considered more than neurological nosology.

(C) Valitova Irina

DOI (article): https://doi.org/10.32626/2227-6246.2021-52.09-38 
DOI: https://doi.org/10.32626/2227-6246.2021-52

2021. випуск 52

Literature analysis shows that in case of neurological pathology of early-age children, specific developmental conditions are created, which contribute to various and, therefore, uncertain or unpredictable results in the child's development. By the same neurological diagnosis, the severity of developmental disorders as well as developmental delays may differ in different spheres. The outcomes of neurological pathology and correction of developmental disorders vary widely: from almost complete recovery to the preservation of severe disorders, which can contribute to the reinforcement in parents' confidence that there is a fundamental possibility of recovery (curing) of the child, since they are guided by the best possible outcome. Based on this there is a need to justify the variability of the psychophysical development of a child with neurological pathology as well as to establish the structure of disturbed and preserved functions as a scientific basis for building correctional and developmental programs and including parents in their implementation.

The aim of the article is to describe the characteristics and identify individual variants of psychophysical development of children with neurological pathology in the early age.

\section{The tasks of the article}

1. To identify indicators of developmental age in different areas by children with neurological pathology at an early age and to determine the diagnostic value of the indicator of the difference between the chronological and the developmental age.

2. Empirically substantiate the variability of the development of children with neurological pathology at an early age by identifying the typology of development profiles.

\section{Research methods}

To estimate the developmental age of children, the $\mathrm{Mu}$ nich Functional Diagnostics of Development (Munich, 1995) (C) Valitova Irina

DOI (article): https://doi.org/10.32626/2227-6246.2021-52.09-38 
was used. This diagnostic procedure identifies several spheres of child development in the first three years of life: motor development, fine motor skills development, perceptual development, speech development and understanding of speech, social development; the sphere of independence (including self-service skills) is also highlighted for child's second and third year. To each of the development spheres the concept of «developmental age» is applied, which is understood as the psychological age or the level of child's development in each sphere. The developmental and the chronological age coincide, if the child develops in accordance with the age standards. If there is a delay in the development, the developmental age is lower than the chronological age; in case of an advanced child development, the developmental age exceeds the chronological age. Based on the results of the diagnosis a child's development profile is compiled, which reflects the indicators of developmental age in each sphere. The development profile is compared with a horizontal line that indicates the chronological age of a child.

Study sample: children aged one to three years with neurological diagnoses of cerebral palsy $(n=99)$ and CNS PROP $(\mathrm{n}=201)$. The study was conducted in the Brest regional Centre for Medical Rehabilitation of children «Tonus».

\section{Results and their discussion}

Clinical and psychological assessment of child developmental age. Indicators of developmental age in different areas were evaluated according to the following diagnostic signs:

- the sphere of manual skills: actions with objects with one and two hands, actions with small objects, correlating actions, drawing, designing, modelling;

- the sphere of perception: the reaction to sensory stimuli, the perception of single objects and the relations of objects (pads), differentiation by size, colour, shape, simple mental actions;

- the sphere of speech understanding: reaction to the

(C) Valitova Irina

DOI (article): https://doi.org/10.32626/2227-6246.2021-52.09-38 
DOI: https://doi.org/10.32626/2227-6246.2021-52

2021. випуск 52

word, an understanding of simple and complex verbal instructions, recognition of objects and actions in the picture, understanding words that denote properties of objects, understanding of complex sentences, understanding of the body names parts, understanding of questions about the appointment of objects etc.;

- the sphere of speech: use active individual speech sounds, complex sounds, syllables, words, phrases, sentences;

- self-service sphere: the ability to drink and eat, to use a spoon and a fork, to wash, to dress, hygienic skills, etc.;

- the sphere of social development: reaction to a person, participation in the communication, use of various means of communication, inclusion into joint activities with an adult, story play, understanding of emotions, empathy, etc.

The assessment of the child's developmental age (DA) is based on a comparison of the child's achievements with the performance indicators of tasks corresponding to the chronological age (CA). Figure 1 shows data indicating the level of development of children separately for two nosological groups (CP and CEOD CNS) and two age groups (second and third years of life). These data indicate that there is a similarity in the development profiles for all groups, which is reflected in the lag of all development indicators from the standards reflected in the values of chronological age. However, the degree of difference between developmental age and the chronological age varies by children of different ages and with different diagnoses as well as in different spheres of development. The largest lag - $\mathbf{1 1 . 1}$ months - is observed in the field of self-service, the smallest lag - 2.3 months - in the field of speech understanding.

Indicators of developmental age in two age groups of children with cerebral palsy and CEOD CNS do not significantly differ: the values of the indicator of manual skills age, perception age, self-service age and social age is $\mathbf{0 . 4 - 0 . 5}$ months higher in the group CEOD CNS; the values of the speech understanding (c) Valitova Irina

DOI (article): https://doi.org/10.32626/2227-6246.2021-52.09-38 
age is 0.3 months higher in the group with cerebral palsy; metrics of speech age development are the same in both groups.

Comparing the figures in the same age group of children with different diagnosis revealed more similarities than differences: in the group of second year of life only indicators of perception varied significantly (at 1 month), other indicators were equal. In groups of third year of life the values of indicators in all spheres differ by less than 1 month.

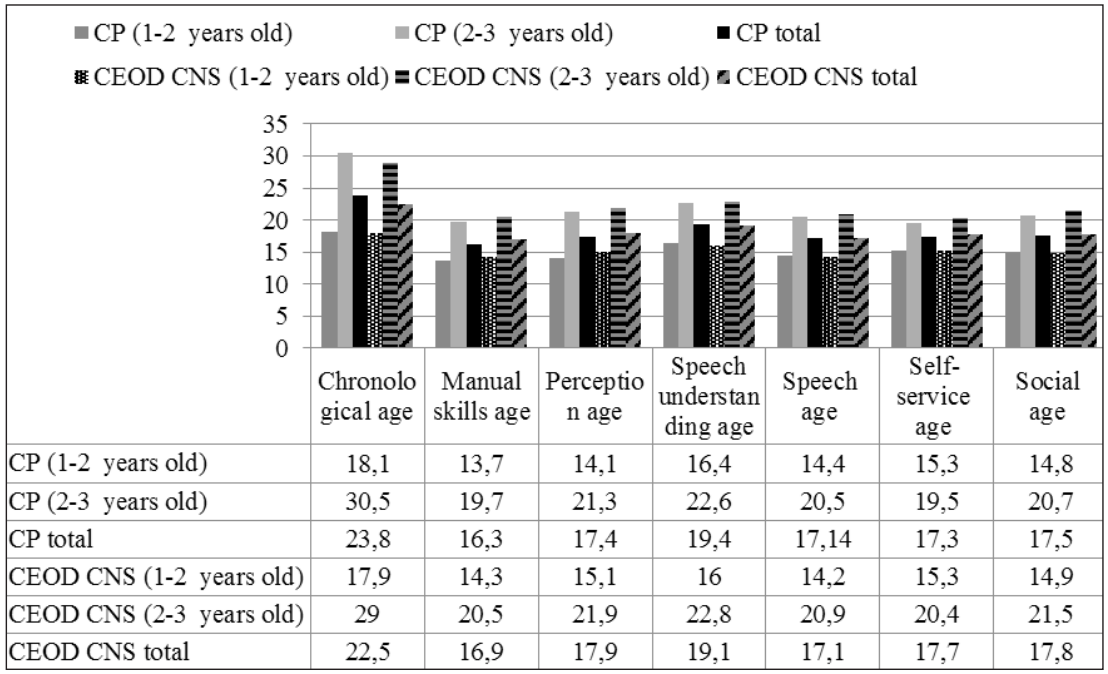

Fig. 1. Developmental age of children, average values in months

Meanwhile, significant differences between the indicators of two to three years old should be emphasized. In the group of children with cerebral palsy the difference in chronological age between the two and third year of life is 12.4 months, while the difference in manual skills age is 6 months, perception age -7.2 months, speech understanding age -3.34 months, speech age -3 months, self-service age -2 months, social development age -3.2 months.

(c) Valitova Irina

DOI (article): https://doi.org/10.32626/2227-6246.2021-52.09-38 
DOI: https://doi.org/10.32626/2227-6246.2021-52

2021. випуск 52

The same differences are observed comparing children from different age groups diagnosed with the CEOD CNS: the difference of children's chronological age between the second and third year of life is 11.1 months, while the difference in manual skills age is 6.2 months, perception age -6.8 months, speech understanding age -6.8 months, speech age -6.8 per month, self-service age -5.1 per month, social development age -6.6 months.

These data indicate a slowdown in the developmental process by children with neurological pathology at the third year of life compared to the second year of life, since under favourable conditions the increase of the developmental indicator values should coincide with the increase of the values of chronological age.

The smaller the increase in the values of developmental age is, the slower the process of psychological development of a child is. The smallest increase is marked in the indicators of manual skills age, self-service age, speech age, speech understanding age and social development age of children with cerebral palsy. The slowing down in the developmental process is more typical for children with cerebral palsy compared to children with CEOD CNS.

The indicator of the discrepancy between children's chronological and developmental age and its diagnostic significance. The difference between the children's chronological and their developmental age in different spheres allows us to estimate, in which spheres the child development differs from the indicators of chronological age and to what extent. Values of this indicator close to zero indicate that there is no lag in this sphere, but values close to the value of chronological age indicate a severe developmental lag in this sphere.

The data in the Figure 2 shows a wide range of differences in the CA-DA index, which differs significantly in different age and nosological groups. In the groups of children of the (C) Valitova Irina

DOI (article): https://doi.org/10.32626/2227-6246.2021-52.09-38 
second and third years of life, the indicator of CA-DA significantly differs statistically in all spheres (t-test, $\mathrm{p}=0.000$ ).

The highest values of the discrepancy indicator are observed in all spheres in the group of cerebral palsy (2-3 years), while they are higher than in another groups: from 11.1 months in the field of self-service, 10.8 months in the field of manual skills, $\mathbf{1 0 . 5}$ months in the field of speech, 9.8 months in the field of social development, 9.2 months in the field of perception, 8 months in the field of speech understanding.

The developmental lag of a child with cerebral palsy at the third year of life is from 8 to 11 months. In the group of children with cerebral palsy (1-2 years), the values of the CA-DA index are significantly lower, they range from 4.4 in the field of manual skills to 2.4 in the field of speech comprehension. Therefore the lag in the development of a child with cerebral palsy at the second year of life is from 4.4 to $2-4$ months.

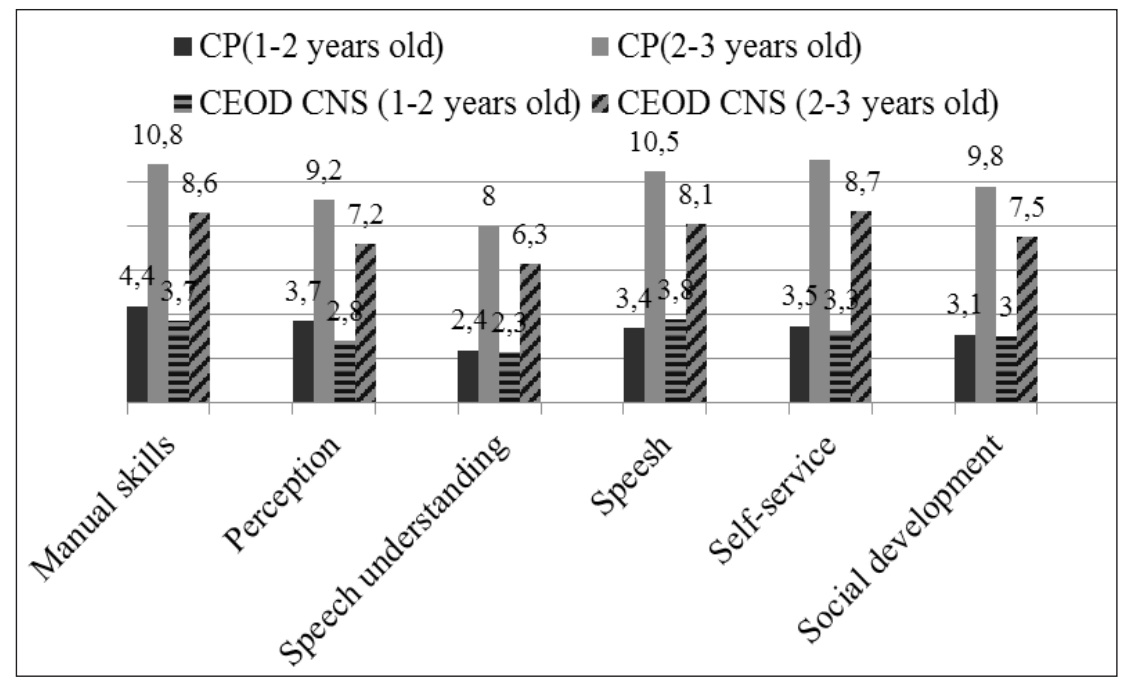

Fig 2. Differences between chronological age and children's developmental age (CA-DA), in months 
These data prove that at the third year there is a slowdown in the tempo of development of a child with cerebral palsy, which is manifested in an increase of difference between the indicators of normal development at a given chronological age and the child's achievements in all spheres of development. Especially obvious lag is in the development of self-service, manual skills and active speech. To a somewhat lesser extent there is a lag in the development of speech understanding, social development and perception.

In the group of children with CEOD CNS, the value of the CA-DA discrepancy is significantly lower than in the group of children with cerebral palsy. In the group of children at the third year of life values of the index vary from 8.7 months in the field of self-service, 8.6 months - in the field of manual skills, 8.7 months - in the field of speech development, to 7.5 months - in the sphere of social development, 7.2 - months in the field of perception and 6.3 months - in the area of comprehension.

Thus the lag in the development of children with CEOD CNS at the third year of life is 6-8 months. In the group of children at the second year of life with this diagnosis the indicators of discrepancies between chronological age and developmental age are ranging from 5.68 months in the field of manual skills to 3.9 months in the sphere of comprehension, the lag of development is 4-6 months. At the third year there is a slowdown in the development of a child with CEOD CNS, which is especially evident in the areas of self-service, manual skills and speech development.

The relationship of children's developmental age indicators in different spheres. The data of the correlation analysis (Spearman quotients) between chronological age indicators and developmental age indicators in two nosological and two age groups of children are presented below. The results for two age groups are in Tables 1 and 2 .

(C) Valitova Irina

DOI (article): https://doi.org/10.32626/2227-6246.2021-52.09-38 
Results of the correlational analysis in the group of children at the second year of life ( $\mathrm{r}-$ correlation quotients)

\begin{tabular}{|c|c|c|c|c|c|c|c|}
\hline & 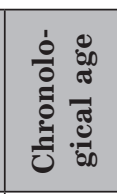 & 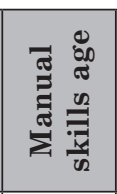 & 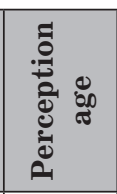 & 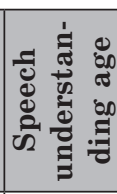 & 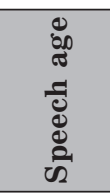 & 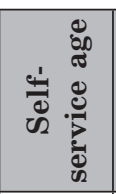 & 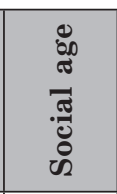 \\
\hline Chronological age & 1.000 & $0.512^{* * *}$ & $0.534^{* * *}$ & $0.521^{\text {** }}$ & $0.541^{\text {* }}$ & $0.559^{* \ldots}$ & $0.542^{* *}$ \\
\hline Manual skills age & $0.512^{* *}$ & 1.000 & $0.922^{* *}$ & $0.817^{* *}$ & $0.816^{\text {** }}$ & $0.884^{* * *}$ & $0.908^{* *}$ \\
\hline Perception age & $0.534^{* *}$ & $0.922^{* * *}$ & 1.000 & $0.835^{* *}$ & $0.838^{* *}$ & $0.861^{* *+1}$ & $0.928^{* *}$ \\
\hline $\begin{array}{l}\text { Speech under- } \\
\text { standing age }\end{array}$ & $0.521^{* *}$ & $0.817^{* * *}$ & $0.835^{* *}$ & 1.000 & $0.831^{* *}$ & $0.806^{* *}$ & $0.859^{* *}$ \\
\hline Speech age & $0.541^{\text {** }}$ & $0.816^{* *}$ & $0.838^{* *}$ & $0.831^{\text {** }}$ & 1.000 & $0.769^{* \ldots}$ & $0.876^{\text {** }}$ \\
\hline Self-service age & $0.559^{* *}$ & $0.884^{* *}$ & $0.861^{* * *}$ & $0.806^{\text {** }}$ & $0.769^{* * *}$ & 1.000 & $0.883^{\text {** }}$ \\
\hline Social age & $0.542^{* *}$ & $0.908^{* * *}$ & $0.928 *$ & $0.859^{* *}$ & $0.876^{\text {* }}$ & $0.883^{* * * *}$ & 1.000 \\
\hline
\end{tabular}
$* * \mathrm{p}=0.000$.

Table 2

Results of the correlational analysis in the group of children at the third year of life ( $\mathrm{r}-$ correlation quotients)

\begin{tabular}{|c|c|c|c|c|c|c|c|}
\hline & 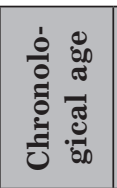 & 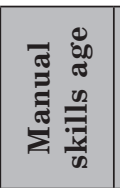 & 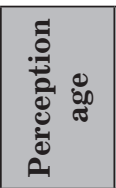 & 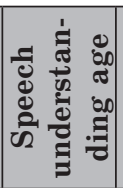 & 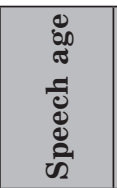 & 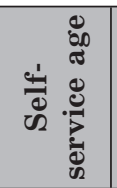 & 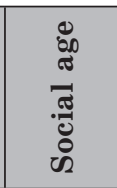 \\
\hline Chronological age & 1.000 & $0.185^{*}$ & $0.222^{*}$ & $0.281^{* *}$ & $0.220^{*}$ & 0.136 & $0.208^{*}$ \\
\hline Manual skills age & $0.185^{*}$ & 1.000 & $0.903^{* *}$ & $0.796^{* *}$ & $0.727^{\text {*a }}$ & $0.903^{* *}$ & $0.881^{\text {** }}$ \\
\hline Perception age & $0.222^{*}$ & $0.903^{* * m}$ & 1.000 & $0.830^{* *}$ & $0.765^{* *}$ & $0.879^{* *}$ & $0.890^{* *}$ \\
\hline $\begin{array}{l}\text { Speech under- } \\
\text { standing age }\end{array}$ & $0.281^{* *}$ & $0.796^{* *}$ & $0.830^{* *}$ & 1.000 & $0.808^{* *}$ & $0.813^{* *}$ & $0.860^{\text {** }}$ \\
\hline Speech age & $0.220^{*}$ & $0.727^{* * *}$ & $0.765^{* *}$ & $0.808^{* *}$ & 1.000 & $0.724^{* *}$ & $0.826^{* *}$ \\
\hline Self-service age & 0.136 & $0.903^{* *}$ & $0.879 \div$ & $0.813^{* *}$ & $0.724^{* *}$ & 1.000 & $0.906^{\text {** }}$ \\
\hline Social age & $0.208^{*}$ & $0.881^{* * *}$ & $0.890^{* *}$ & $0.860^{* *}$ & $0.826^{* *}$ & $0.906^{* *}$ & 1.000 \\
\hline
\end{tabular}
$* \mathrm{p} \leq 0.05 ; * * \mathrm{p}=0.000$. 
DOI: https://doi.org/10.32626/2227-6246.2021-52

2021. випуск 52

The values of the correlation coefficients show that the indicators of chronological age are strongly positively related to the values of the developmental age in all spheres, that is, with the increase of the child's chronological age, the indicators of his developmental age in all spheres also increase. Since the level of development increases by children with cerebral palsy and CEOD CNS, we can say that they do not remain at the same level of development, but develop constantly.

All indicators of the developmental age in all spheres highly correlate with each other, which prove the close connection of all spheres of development at an early age as well as their simultaneous development.

In the second year of life the children with neurological pathology have a high- and very high-degree relationship between all spheres of development, especially the following three areas are closely related: manual skills, perception and social development.

In the period from one to two years, a child learns various actions with objects, which affects the development of perception, forming if a child interacts with an adult. Chronological age is associated with the indicators of the developmental age by the correlation of an average degree at $p<0.05$, which indicates the absence of a very close relationship between them and a certain degree of independence of the child's level of development starting from his chronological age.

The relationship between chronological age and developmental age in all spheres is significantly weakened by children with neurological pathology at the third year of life: the correlation between them is weak and positive, which indicates a slower rate of child development. There is no connection between a chronological and a self-service age at the third year of life: children have difficulties in accumulating self-service skills, which is probably due to a lag in the development of manual skills and perception.

(C) Valitova Irina

DOI (article): https://doi.org/10.32626/2227-6246.2021-52.09-38 
A very high correlation between the indicators of manual skills, perception age, self-service age and social development age is found out in the group of third year children. These areas are developed in a particularly close relationship since the development of manual skills, perception and communication with adults is necessary for mastering self-service skills.

Types of child development profiles. The analysis of individual types of development profiles by young children allowed us to distinguish several types of development profiles based on the following criteria: uniformity / unevenness of the profile; the degree of lag in development compared with chronological age; the presence of «descending» spheres of development: lag in the development of some spheres while preserving other spheres. Based on these criteria the following types of child developmental age profiles were identified (Table 3).

Table 3

Types of developmental profiles by early age children with neurological pathology

\begin{tabular}{|c|c|c|c|c|c|}
\hline Type & Name & Profile Characteristics & $\begin{array}{l}\text { Diag- } \\
\text { nosis }\end{array}$ & $\begin{array}{c}\text { Num- } \\
\text { ber }\end{array}$ & In $\%$ \\
\hline $\begin{array}{c}\text { Type } \\
1\end{array}$ & $\begin{array}{l}\text { Regular (slight } \\
\text { reduction) }\end{array}$ & $\begin{array}{c}\text { Regular slight decrease } \\
\text { in the indicators } \\
\text { of developmental age } \\
\text { in all spheres }\end{array}$ & G80.1 & 35 & 11.67 \\
\hline $\begin{array}{l}\text { Type } \\
2\end{array}$ & $\begin{array}{l}\text { Regular } \\
\text { (significant } \\
\text { reduction) }\end{array}$ & $\begin{array}{c}\text { Regular significant } \\
\text { decrease in the } \\
\text { indicators of } \\
\text { developmental age } \\
\text { in all spheres } \\
\end{array}$ & $\begin{array}{l}\text { G96.8 } \\
\text { G80.0 } \\
\text { G80.1 } \\
\text { G80.4 }\end{array}$ & 68 & 22.6 \\
\hline $\begin{array}{l}\text { Type } \\
3\end{array}$ & $\begin{array}{l}\text { Irregular } \\
\text { reduction }\end{array}$ & $\begin{array}{l}\text { The indicators of } \\
\text { developmental age } \\
\text { decrease in all spheres, } \\
\text { but the degree of } \\
\text { decline differs }\end{array}$ & $\begin{array}{l}\text { G80.0 } \\
\text { G80.1 } \\
\text { G80.4 }\end{array}$ & 70 & 23.3 \\
\hline
\end{tabular}

(C) Valitova Irina

DOI (article): https://doi.org/10.32626/2227-6246.2021-52.09-38 


\begin{tabular}{|c|c|c|c|c|c|}
\hline Туре & Name & Profile Characteristics & $\begin{array}{l}\text { Diag- } \\
\text { nosis }\end{array}$ & $\begin{array}{c}\text { Num- } \\
\text { ber }\end{array}$ & In $\%$ \\
\hline \multirow[t]{5}{*}{$\begin{array}{c}\text { Type } \\
4\end{array}$} & $\begin{array}{l}\text { Descending } \\
\text { profile }\end{array}$ & $\begin{array}{l}\text { Indicators of the } \\
\text { developmental age } \\
\text { that are close to the } \\
\text { chronological age } \\
\text { or a slight lag with } \\
\text { a decrease in the } \\
\text { level of development } \\
\text { indicators in certain } \\
\text { spheres («descending } \\
\text { developmental } \\
\text { spheres») including: }\end{array}$ & $\begin{array}{l}\text { G80.1 } \\
\text { G80.4 } \\
\text { G96.8 }\end{array}$ & 77 & 25.67 \\
\hline & \multirow{4}{*}{$\begin{array}{l}\text { Variants of } \\
\text { descending } \\
\text { functions }\end{array}$} & $\begin{array}{c}\text { speech and social } \\
\text { development }\end{array}$ & & 10 & 3.33 \\
\hline & & $\begin{array}{c}\text { perception (cognitive } \\
\text { development) }\end{array}$ & & 6 & 2.0 \\
\hline & & speech & & 23 & 7.66 \\
\hline & & $\begin{array}{c}\text { manual skills and } \\
\text { self-service }\end{array}$ & & 38 & 12.7 \\
\hline $\begin{array}{c}\text { Type } \\
5\end{array}$ & $\begin{array}{l}\text { Approach to } \\
\text { chronological } \\
\text { age }\end{array}$ & $\begin{array}{c}\text { Developmental } \\
\text { indicators close to } \\
\text { the chronological age } \\
\text { or a slight lag } \\
\text { in the indicators } \\
\text { of the developmental } \\
\text { age from the } \\
\text { chronological age }\end{array}$ & $\begin{array}{l}\text { G96.8 } \\
\text { G80.1 } \\
\text { G80.2 }\end{array}$ & 46 & 15.3 \\
\hline $\begin{array}{c}\text { Type } \\
6\end{array}$ & $\begin{array}{l}\text { Exceeding the } \\
\text { chronological } \\
\text { age }\end{array}$ & $\begin{array}{c}\text { Excess of indicators of } \\
\text { the developmental age } \\
\text { in comparison with the } \\
\text { chronological age }\end{array}$ & $\begin{array}{l}\text { G80.1 } \\
\text { G80.2 }\end{array}$ & 4 & 1.33 \\
\hline & Total & & & 300 & 100 \\
\hline
\end{tabular}

Figure 3 shows the number of different types of development profiles. Different types of child development profiles occur with different frequency.

(C) Valitova Irina

DOI (article): https://doi.org/10.32626/2227-6246.2021-52.09-38 


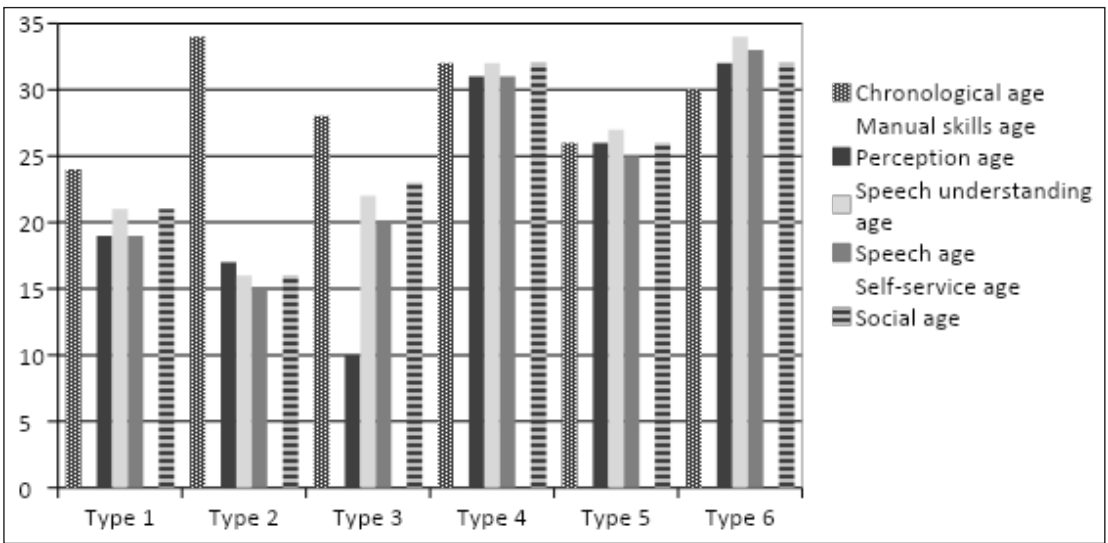

Fig. 3. Examples of the developmental profiles types

More often there is a descending profile (25.7\%), a regular (significant reduction) profile $-22.6 \%$, an irregular reduction profile $-23.3 \%$, an approach to chronological age profile $15.4 \%$. There is a rather high frequency $(15.4 \%)$ of the profile type 5 «approach to chronological age»: the sixth part of children are developed quite successfully, their development indicators either correspond to the chronological age or slightly differ from it. In $1.18 \%$ of cases, the development indicators of children exceed the indicators of their chronological age (type 6).

Irregularity or heterochrony of child development in different spheres occurs in half of the cases (49\%); among these cases one part of children show developmental delays in all spheres, and the other part - only in one or two spheres, while in the remaining spheres the development is approaching the age norms, that is, these spheres can be considered relatively unharmed.

A profile with a lag in the development of one sphere is called "descending»: as the lagging due to the frequency of symptoms in the whole sample is identified in the spheres of 
DOI: https://doi.org/10.32626/2227-6246.2021-52

2021. випУСК 52

manual skills and self-service (13\%), the development of speech $(7.5 \%)$, spheres of speech and social development, the sphere of perception $(2 \%)$. Thus the descending (lagging) sphere is more often the sphere of actions with objects and the area of speech development.

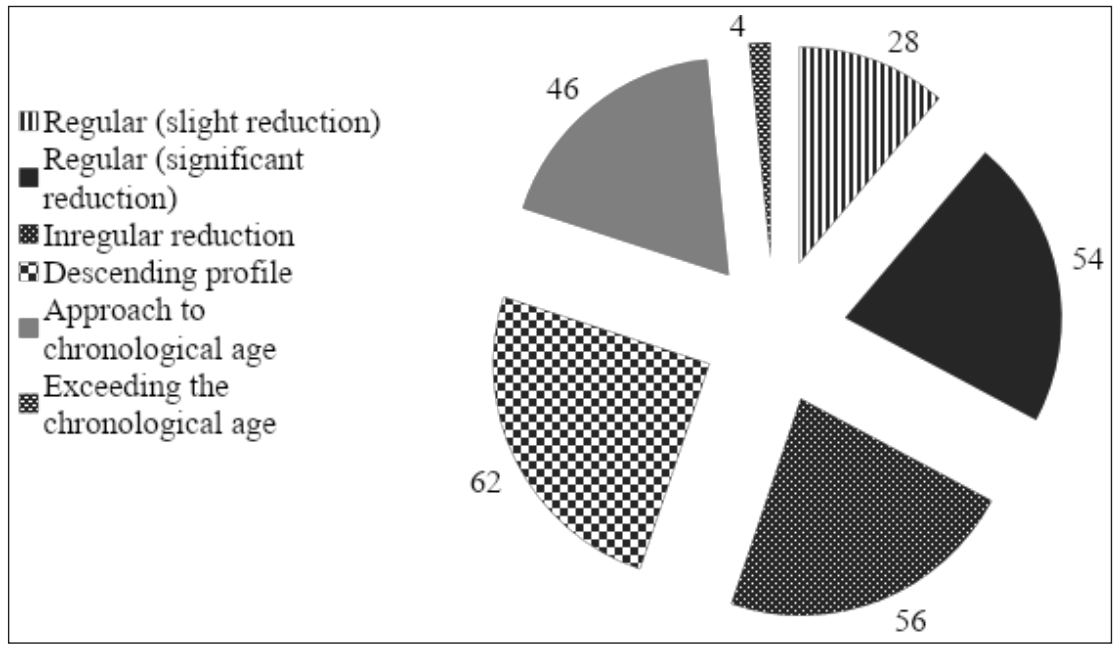

Fig. 4. Types of development profiles at early age children with neurological pathology

Types of development profiles at children of different nosological groups. Comparing the types of development profiles with nosological categories, it is hardly possible to establish their stable relationship since different types of profiles are found among children with the same diagnosis. However there are exceptions. Thus, the diagnosis G80.2 (cerebral palsy, hemiplegia) occurs only among children with profiles of type 5 and type 6 . The children diagnosed with G83.2 (plexitis) have only types 5 and 6 of profile.

Among children with a diagnosis of G80.4 (cerebral palsy, ataxic cerebral palsy), the profile «regular (significant reduction)» and «irregular reduction» are more common and only (C) Valitova Irina

DOI (article): https://doi.org/10.32626/2227-6246.2021-52.09-38 
in rare cases there is a "descending profile» and a profile «approaching chronological age».

The diagnosis of G80.1 (cerebral palsy, spastic diplegia) occurs among children with all types of development profiles. The diagnosis of G80.0 (cerebral palsy, spastic cerebral palsy, tetraplegia) occurs among children with the development profiles «regular (significant reduction)» and «irregular reduction».

\section{Conclusion}

1. The psychophysical development of early age children with neurological pathology is carried out in the activities and child's communication and refers to the motor, mental, speech and social spheres. Indicators of the child's developmental age reflect the level of his development in the relevant sphere in comparison with the standard indicators for chronological age. Among early age children with neurological pathology the indicators of their developmental age in all spheres increase with the increase of child's chronological age, which indicates the dynamics of psychophysical development in the period from one to three years.

2. All indicators of developmental age in all spheres are connected with each other by a high correlation at $\mathrm{p}<0.01$, which proves the relationship of all spheres at an early age as well as their simultaneous development.

3. A regularity of slowing down the development tempo of a child with neurological pathology with age increasing is established. The value of the indicator of the discrepancy between the chronological and the developmental age increases in the third year of life in comparison with the second year of life. In the third year of life the relationship between the chronological and the developmental age is significantly weakened in all spheres, but the slowdown in the child development in the spheres of self-service, manual skills and speech development is especially obvious.

(C) Valitova Irina

DOI (article): https://doi.org/10.32626/2227-6246.2021-52.09-38 
DOI: https://doi.org/10.32626/2227-6246.2021-52

2021. випуск 52

4. Different types of development profiles of a child with neurological pathology were found based on a set of criteria (regularity / irregularity of the profile, the degree of developmental lag compared with the chronological age, the presence of a developmental lag in some spheres by maintenance of relatively unharmed other spheres).

The types of development profiles of children with neurological pathology are presented in a sample with a different frequency: the most common profiles are those with a significant decrease in the development indicators, less often - profiles with a slight decrease in the development indicators and the profile with an excess of chronological age indicators is found in rare cases.

A falling profile with a lag in the development of one sphere is more often found. The types of development profiles of children with neurological pathology are presented in the general sample with a different frequency: the most common profiles are those with a significant decrease in the development indicators, less often - profiles with a slight decrease in the development indicators, and the profile with an excess of chronological age indicators is found in rare cases.

Irregularity or heterochrony of the child development in different spheres occurs in half of the cases; one part in these cases shows developmental delays in all spheres and the other part - only in one or two spheres, while in the remaining spheres the development is approaching the age norms. A descending profile with a lag in the development of one sphere is more often found in a sphere of actions with objects and speech.

5. The types of development profiles are not strictly related to nosological categories since different types of profiles are found among children with the same neurological diagnosis. It was found out that the children with a diagnosis of G80.2 (cerebral palsy, hemiplegia) have only types that indi(C) Valitova Irina

DOI (article): https://doi.org/10.32626/2227-6246.2021-52.09-38 
cate a sufficiently favourable course of child development. The diagnosis of G80.0 (cerebral palsy, spastic cerebral palsy, tetraplegia) occurs among children with developmental profiles that indicate a significant lag in the development and limit the favourable prognosis of the child development. The diagnosis of G80.1 (cerebral palsy, spastic diplegia) occurs among children with all types of development profiles. So, this form of cerebral palsy at an early age implies a variety of options for the prognosis of the child development.

6. The identified six types of development profiles indicate a wide range of development options for children with neurological pathology at the age of one to three years. Profile development reflects the structure of the defect and allows to define either lagging or an unharmed function, set objectives for a remedial work as well as to determine the zone of proximal development of a child.

The establishment of patterns of child development, and especially the patterns of slowing down the tempo of child development with age, has not only theoretical, but also practical importance for the work of a therapist with mothers who have no idea about the slowdown in development, so they are confident in the possibility of a complete cure for the child.

Further studies of early age children with neurological pathology development peculiarities should be carried out using methods aimed to diagnose the characteristics of communication and activity of children. An important task of the new research is to identify the maternal attitude towards young children with developmental disorders of different degrees.

\section{Literature}

Архипова Е. Ф. Коррекционная работа с детьми с церебральным параличом (доречевой период): монография. Москва : Просвещение, 1989. 86 c.

Барашнев Ю. И. Перинатальная неврология. Москва : Триада-Х, 2001. 640 c.

(C) Valitova Irina

DOI (article): https://doi.org/10.32626/2227-6246.2021-52.09-38 
Браткова М. В. Формирование предметных действий у детей раннего возраста с органическим поражением центральной нервной системы: дисс. ... канд. пед. наук: 13.00.03. Москва, 2006. 183 с.

Ермоленко Н. А., Скворцов И. А., Неретина А. Клинико-психологический анализ развития двигательных, перцептивных, интеллектуальных и речевых функций у детей с церебральными параличами. Журнал неврологии и психиатрии. 2000. № 3. С. 19-23.

Кузнецова Л. В. и др. Основы специальной психологии: учеб. пособие / под ред. Л. В. Кузнецовой. Москва : Издательский центр «Академия», 2002. $480 \mathrm{c.}$

Крутякова Е. Н. Развитие коммуникативной деятельности у детей раннего возраста с церебральным параличом: дисс. ... канд. пед. наук: 13.00.03. Москва, 2011. 132 с.

Кукуруза Г. В. Міждисциплінарна оцінка порушень психомоторного та соціально-емоційного розвитку у дітей раннього віку в системі раннього втручання. Вісник Харківського нащіонального університету імені В. Н. Каразіна. Серія: Психологія. 2012. № 1009. Вип. 49. С. 80-83.

Лебединский В. В. Нарушения психического развития у детей. Москва : Изд-во МГУ, 1985. 168 с.

Мамайчук И. И. Психокоррекционные технологии для детей с проблемами в развитии. Санкт-Петербург : Речь, 2003. 400 с.

Мастюкова Е. М., Ипполитова М. В. Нарушение речи у детей с церебральным параличом. Москва : Просвещение, 1985. 204 с.

Пальчик А. Б. Эволюционная неврология. Санкт-Петербург : Питер, 2002. $384 \mathrm{c}$.

Приходько О. Г. Ранняя помощь детям с церебральным параличом в системе комплексной реабилитации: монография. Санкт-Петербург : Изд-во РГПУ им. А. И. Герцена, 2008. 208 с.

Синдяк С. А. Организационно-педагогические условия коррекции психофизического развития детей раннего возраста с резидуально-органическим поражением центральной нервной системы в условиях специализированного медицинского учреждения: дисс. ... канд. пед. наук: 13.00.03. Екатеринбург, 2007. 186 с.

Смычек В. Б. Реабилитация больных и инвалидов. Москва : Медицинская литература, 2009. 560 с.

Тишкова А. В. Развитие и совершенствование коррекционно-педагогической помощи детям раннего возраста с психоневрологической патологией: дисс. ... канд. пед. наук: 13.00.03. Москва, 2004. 145 с.

Хачатрян Л. Г. Ранние и отдаленные проявления перинатального поражения нервной системы у детей раннего возраста: дисс. ... д-ра мед. наук: 14.00.09. Москва, 2003. 283 с.

(c) Valitova Irina

DOI (article): https://doi.org/10.32626/2227-6246.2021-52.09-38 
DelCarmen-Wiggins, R., \& Carter, A. (Eds.) Handbook of Infant, Toddler, and Preschool Mental Health Assessment (2004). New York : Oxford University Press. 530 p.

Hellbruegge, Theodor (Ed.) (1995). Munich Functional Developmental Diagnosis for the First, Second and Third Year of Life. Kerala : Jeevan Prakash Child Centre. 332 p.

Henry, L. N., \& et al. (2018). Trajectories of cognitive development in toddlers with language delays. Research in Developmental Disabilities. doi.org/10.1016/j.ridd.2018.04.005. Date of access 26.07.2018.

Hidecker, M. J. C., \& et al. (2018). Early Predictors and Correlates of Communication Function in Children with Cerebral Palsy. Journal of Child Neurology. Vol. 33 (4). P. 275-285.

Houwen, S., \& et al. (2016). The interrelationships between motor, cognitive, and language development in children with and without intellectual and developmental disabilities. Research in Developmental Disabilities. No. 53-54. P. 19-31.

Hustad, K. C., \& et al. (2014). Speech and language development in 2-yearold children with cerebral palsy. Development Neurorehabilitation. Vol. 17. P. 167-175.

McManus, B., Robinson, C. C., \& Rosenberg, S. A. (2016). Identifying Infants and Toddlers at High Risk for Persistent Delays. Maternal Child Health Journal. Vol. 20. P. 639-645.

Peters, H. A., O., \& Bredel-Geißler, M. Bartsch (2017). Ätiologie und multiprofessionelle Diagnostik bei Kinder mit Intelligenzminderung. Entwicklungsstörungen und chronische Erkrankungen. Diagnose, Behandlungsplanung und Familienbegleitung. München : Verlag Schmidt-Römhild. S. 91-102.

Voigt, F. (2017). Nachsorge und prospektive Entwicklungsplannung bei globalen Entwicklungsstörungen. Entwicklungsstörungen und chronische Erkrankungen. Diagnose, Behandlungsplanung und Familienbegleitung. München : Verlag Schmidt-Römhild. S. 91-102.

Zampini, L. (2018). Vocal and gestural productions of 24 month old children with sex chromosome trisomies. International Journal of Language \& Communication Disorders. Vol. 53. No. 1. P. 171-181.

\section{References}

Arkhipova, E. F. (1989). Korrektsionnaia rabota s detmi s tserebralnym paralichom (dorechevoi period) [Correctional work with children with cerebral palsy (pre-speech period)]. Moskva : Prosveshcheniie [in Russian].

(c) Valitova Irina

DOI (article): https://doi.org/10.32626/2227-6246.2021-52.09-38 
DOI: https://doi.org/10.32626/2227-6246.2021-52

2021. виПуск 52

Barashnev, Yu. I. (2001). Perinatalnaia nevrologiia [Perinatal neurology]. Moskva : Triada-Kh [in Russian].

Bratkova, M. V. (2006). Formirovaniie predmetnykh deistvii u detei rannego vozrasta $\mathrm{s}$ organicheskim porazheniiem tsentralnoi nervnoi sistemy [Formation of subject actions in young children with organic damage to the central nervous system]. Candidate's thesis. Moskva.

Yermolenko, N. A., Skvortsov, I. A., \& Neretina, A. (2000). Kliniko-psikhologicheskii analiz razvitiia dvigatelnykh, pertseptivnykh, intellektualnykh i rechevykh funktsii u detei s tserebralnymi paralichami [Clinical and psychological analysis of the development of motor, perceptual, intellectual and speech functions in children with cerebral palsy]. Zhurnal nevrologii i psikhiatrii - Journal of Neurology and Psychiatry, 3, 19-23 [in Russian].

Kuznetsova, L. V. i dr. (2002). Osnovy spetsialnoi psikhologii [Fundamentals of special psychology]. L. V. Kuznetsova (Ed.). Moskva : Izdatelskii tsentr "Akademiia» [in Russian].

Krutiakova, E. N. (2011). Razvitiie kommunikativnoi deiatelnosti u detei rannego vozrasta s tserebralnym paralichom [Development of communicative activity in young children with cerebral palsy]. Candidate's thesis. Moskva.

Kukuruza, H. V. (2012). Mizhdystsyplinarna otsinka porushen psykhomotornoho ta sotsialno-emotsiinoho rozvytku u ditei rannioho viku $\mathrm{v}$ systemi rannioho vtruchannia [Interdisciplinary assessment of psychomotor and socio-emotional development of young children in the early intervention system]. Visnyk Kharkivskoho natsionalnoho universytetu imeni V. N. Karazina - Bulletin of Kharkiv V. N. Karazin National University. Series: Psychology, 1009, 49, 80-83 [in Ukrainian].

Lebedinskii, V. V. (1985). Narusheniia psikhicheskogo razvitiia u detei [Violations of mental development in children]. Moskva : Izdatelstvo MGU [in Russian].

Mamaichuk, I. I. (2003). Psikhokorrektsionnyie tekhnologii dlia detei s problemami $v$ razvitii [Psychotechnologies for children with developmental problems]. Sankt-Peterburg : Rech [in Russian].

Mastiukova, E. M., \& Ippolitova, M. V. (1985). Narusheniie rechi u detei s tserebralnym paralichom [Speech disorders in children with cerebral palsy]. Moskva : Prosveshcheniie [in Russian].

Palchik, A. B. (2002). Evoliutsionnaia nevrologiia [Evolutionary neurology]. Sankt-Peterburg : Piter [in Russian].

Prikhodko, O. G. (2008). Ranniaia pomoshch detiam s tserebralnym paralichom $v$ sisteme kompleksnoi reabilitatsii [Early care for children with (c) Valitova Irina

DOI (article): https://doi.org/10.32626/2227-6246.2021-52.09-38 
cerebral palsy in the system of complex rehabilitation]. Sankt-Peterburg : Izd-vo RGPU im. A. I. Gertsena [in Russian].

Sindiak, S. A. (2007). Organizatsionno-pedagogicheskiie usloviia korrektsii psikhofizicheskogo razvitiia detei rannego vozrasta s rezidualno-organicheskim porazheniiem tsentralnoi nervnoi sistemy $\mathrm{v}$ usloviiakh spetsializirovannogo meditsinskogo uchrezhdeniia [Organizational and pedagogical conditions for the correction of the psychophysical development of young children with a residual organic lesion of the central nervous system in the conditions of a specialized medical institution]. Candidate's thesis. Ekaterinburg [in Russian].

Smychek, V. B. (2009). Reabilitatsiia bolnykh i invalidov [Rehabilitation of patients and invalids]. Moskva : Meditsinskaia literatura [in Russian].

Tishkova, A. V. (2004). Razvitiie i sovershenstvovaniie korrektsionno-pedagogicheskoi pomoshchi detiam rannego vozrasta s psikhonevrologicheskoi patologiiei [Development and improvement of correctional and pedagogical assistance to young children with psychoneurological pathology]. Candidate's thesis. Moskva [in Russian].

Khachatrian, L. G. (2003). Ranniie i otdalennyie proiavleniia perinatalnogo porazheniia nervnoi sistemy $u$ detei rannego vozrasta [Early and remote manifestations of perinatal damage to the nervous system in young children]. Candidate's thesis. Moskva [in Russian].

DelCarmen-Wiggins, R., \& Carter, A. (Eds.) (2004). Handbook of Infant, Toddler, and Preschool Mental Health Assessment. New York : Oxford University Press.

Hellbruegge, Theodor (Ed.) (1995). Munich Functional Developmental Diagnosis for the First, Second and Third Year of Life. Kerala : Jeevan Prakash Child Centre.

Henry, L. N., \& et al. (2018). Trajectories of cognitive development in toddlers with language delays. Research in Developmental Disabilities. doi.org/10.1016/j.ridd.2018.04.005. Date of access 26.07.2018.

Hidecker, M. J. C., \& et al. (2018). Early Predictors and Correlates of Communication Function in Children with Cerebral Palsy. Journal of Child Neurology, 33 (4), 275-285.

Houwen, S., \& et al. (2016). The interrelationships between motor, cognitive, and language development in children with and without intellectual and developmental disabilities. Research in Developmental Disabilities, 53-54, 19-31.

Hustad, K. C., \& et al. (2014). Speech and language development in 2-yearold children with cerebral palsy. Development Neurorehabilitation, $17,167-175$.

(C) Valitova Irina

DOI (article): https://doi.org/10.32626/2227-6246.2021-52.09-38 
McManus, B., Robinson, C. C., \& Rosenberg, S. A. (2016). Identifying Infants and Toddlers at High Risk for Persistent Delays. Maternal Child Health Journal, 20, 639-645.

Peters, H. A., Bredel-Geißler, O., \& Bartsch, M. (2017). Ätiologie und multiprofessionelle Diagnostik bei Kinder mit Intelligenzminderung. Entwicklungsstörungen und chronische Erkrankungen. Diagnose, Behandlungsplanung und Familienbegleitung, (S. 91-102). München : Verlag Schmidt-Römhild [in German].

Voigt, F. (2017). Nachsorge und prospektive Entwicklungsplannung bei globalen Entwicklungsstörungen. Entwicklungsstörungen und chronische Erkrankungen. Diagnose, Behandlungsplanung und Familienbegleitung, (S. 61-72). München : Verlag Schmidt-Römhild [in German].

Zampini, L. (2018). Vocal and gestural productions of 24 month old children with sex chromosome trisomies. International Journal of Language \& Communication Disorders, 53 (1), 171-181.

Валітова Ірина. Закономірності психофізичного розвитку дітей раннього віку з неврологічною патологією

\section{АНОТАЦІЯ}

Мета статmi - описати характеристики і виокремити індивідуальні варіанти психофрізичного розвитку дітей із неврологічною патологією в період раннього віку.

Методи дослідження. Для оцінки віку розвитку дітей використано Мюнхенську Функціональну Діагностику Розвитку, в якій виокремлено такі сррери розвитку дитини, як: руховий розвиток, розвиток дрібної моторики, розвиток перцепції, розвиток мови і розуміння мови, соціальний розвиток, сфера самостійності. Поняття "вік розвитку» розуміється як рівень розвитку дитини в кожній срері. Вибірка дослідження-діти віком від одного до трьох років із неврологічними діагнозами ДЦП $(n=99)$ і НРОУ ЦHC $(n=201)$.

Результати дослідження. У дітей показники віку розвитку в усіх сферах зростають зі збільшенням хронологічного віку дитини, що свідчить про динаміку психофрізичного розвитку в період від одного до трьох років. Значення показника розбіжності хронологічного віку і віку розвитку збільшується у дітей третього року життя, порівняно з дітьми другого року життя, що означає уповільнення темпу розвитку дітей. На підставі сукупності критеріїв виявлено шість типів профілів розвитку дитини (c) Valitova Irina

DOI (article): https://doi.org/10.32626/2227-6246.2021-52.09-38 http://journals.uran.ua/index.php/2227-6246 
DOI: https://doi.org/10.32626/2227-6246.2021-52

2021. ВипУСК 52

з неврологічною патологією, які представлено в загальній вибірці з різною частотою: найчастіше зустрічаються профрілі з істотним зниженням показників розвитку, рідше - профілі з невеликим зниженням показників розвитку, а профріль із перевищенням показників хронологічного віку зустрічається в одиничних випадках. Типи профрілів розвитку жорстко не пов'язані з нозологічними категоріями.

Висновки. Профріль розвитку відображає структуру дефекту в дитини і дає змогу визначити відстаючі й збережені функції, поставити завдання корекційної роботи і визначити зону найближчого розвитку дитини. Установлені закономірності розвитку дитини з неврологічною патологією будуть цікаві лікарям-неврологам, а також мають прикладне значення для роботи з матерями, у яких відсутні уявлення про уповільнення розвитку дитини з віком.

Ключові слова: ранній вік, психофрізичний розвиток, порушення розвитку в дітей, неврологічна патологія, дитячий черебральний параліч, органічні ураження ЦНС, закономірності порушень розвитку, профріль розвитку.

\section{Валитова Ирина. Закономерности психофизического развития детей раннего возраста с неврологической патологией}

\section{АННОТАЦИЯ}

Цель статьи - описать характеристики и выделить индивидуальные варианты психофизического развития детей с неврологической патологией в период раннего возраста.

Методы исследования. Для оценки возраста развития детей использована Мюнхенская Функциональная Диагностика Развития, в которой выделены следующие среры развития ребенка: двигательное развитие, развитие мелкой моторики, развитие перцепции, развитие речи и понимания речи, сочиальное развитие, сфера самостоятельности. Понятие «возраст развития" понимается как уровень развития ребенка в каждой области. Выборка исследования - дети в возрасте от одного года до трех лет с неврологическими диагнозами ДЦП $(n=99)$ и ПРОП ЦНС $(n=201)$.

Результаты исследования. У детей показатели возраста развития во всех сферах возрастают с увеличением хронологического возраста ребенка, что свидетельствует о динамике психофизического развития

(C) Valitova Irina

DOI (article): https://doi.org/10.32626/2227-6246.2021-52.09-38 
DOI: https://doi.org/10.32626/2227-6246.2021-52

2021. випуск 52

в период от одного года до трех лет. Значение показателя расхождения хронологического возраста и возраста развития увеличивается у детей третьего года жизни по сравнению с детьми второго года жизни, что означает замедление темпа развития детей. На основании совокупности критериев выявлены шесть типов профилей развития ребенка с неврологической патологией, которые представлены в общей выборке с разной частотой: наиболее часто встречаются профили с существенным снижением показателей развития, реже - профили с небольшим снижением показателей развития, а профиль с превышением показателей хронологического возраста встречается в единичных случаях. Типы профилей развития жестко не связаны с нозологическими категориями.

Выводы. Профиль развития отражает структуру дефекта у ребенка и позволяет определить отстающие и сохранные функции, поставить задачи коррекционной работы и определить зону ближайшего развития ребенка. Установленные закономерности развития ребенка с неврологической патологией будут интересны врачам-неврологам, а также имеют прикладное значение для работы с матерями, у которых отсутствуют представления о замедлении развития ребенка с возрастом.

Ключевые слова: ранний возраст, психофизическое развитие, нарушения развития у детей, неврологическая патология, детский церебральный паралич, органические поражения ЦНС, закономерности нарушений развития.

Original manuscript received February 09, 2021 Revised manuscript accepted March 15, 2021 